\title{
Synchronization of estrus and ovulation in ewes by means of a progestin treatment combined with either PMSG or PGF $_{2 \alpha}$
}

\author{
Yutaka FukuI, William L. SotTo and Hitoshi ONo \\ Department of Meat Animal Reproduction, Obihiro University of \\ Agriculture and Veterinary Medicine, Obihiro 080.
}

\begin{abstract}
Summary. Effects of an administration of $750 \mathrm{IU}$ pregnant mare serum gonadotropin (PMSG: group I, 13 ewes) and $15 \mathrm{mg}$ prostaglandin $\mathrm{F}_{2 \alpha}\left(\mathrm{PGF}_{2 \alpha}\right.$ : group II, 15 ewes) after a progestin treatment with methyl-acetoxyprogesterone (MAP) through vaginal sponge for 9 days on synchronization of estrus and ovulation, and the subsequent fertility were compared with that of cycling ewes during the breeding season. The changes in plasma steroids (estradiol-17 $\beta$ : $\mathrm{E}_{2}$ and progesterone: $\mathrm{P}$ ) concentrations were also estimated. All treated ewes showed estrus within 5 days after the treatment and all of the 4 laparotomized ewes in each group were ovulated when examined 8 days after the treatment. The number of ovulations in group I appeared to be greater than that in group II (3.25 \pm 0.63 and $1.75 \pm 0.25$ per ewe), although the difference was not significant. Conception rates were expressed non-return (1621 days), pregnancy (50-70 days) diagnosed by a Doppler method, lambing rate and number of lambs born per ewe. There was no significant difference in fertility between the two groups probably due to a small number of ewes used. The changing pattern of plasma concentrations of $E_{2}$ and $P$ was similar between the two groups. The MAP sponge treatment combined with PMSG appears to be more effective than MAP sponge combined with $\mathrm{PGF}_{2 \alpha}$ treatment for synchronization of estrus and ovulation in cycling ewes.
\end{abstract}

(Japan. J. Anim. Reprod., 29, 48-53, 1983)

\section{Introduction}

A low fertility has been reported in ewes treated with progestin for a long period (1316 days $)^{1)}$. Although a combined treatment of progestin for a short-term (7-12 days) with $\mathrm{PGF}_{2 \alpha}$ has been known to improve fertility at the first synchronized estrus in cycling ewes ${ }^{2-4)}$, the study for induction of fertile estrus and ovulation in ewes during the breeding season has been limited on separate effects of PMSG or $\mathrm{PFG}_{2 \alpha}$ following a shortterm progestin treatment.

The purpose of the present study was to compare effects of PMSG and PGF $_{2 \alpha}$ after a short-term (9 days) progestin treatment on synchronization of estrus and ovulation, and the subsequent fertility as well as to demonstrate the hormonal patterns in ewes during and after treatment.

\section{Materials and Methods}

The present study was conducted between September 21st and November 7th, 1981. Twenty-eight Corriedale, Suffolk and Corriedale $\times$ Suffolk adult ewes $(3$ kept at the University Farm, 5 at M Farm and 20 at $\mathrm{H}$ Farm) were randomly allotted into two groups (group I: 13 and group II: 15 ewes). Identification was made by color-branding of body sides in each ewe.

All ewes were pretreated with $60 \mathrm{mg}$ MAP vaginal sponge (Upjohn Co., Australia) for 9 days regardless of the stage of the estrous 
cycle. The sponge insertion was done as described by FukuI and RoBerts ${ }^{3)}$. Immediately after sponge removal, the ewes in group I were treated with a single intramuscular injection of 750 IU PMSG (Teikoku-zōki Co., Japan) in $1.0 \mathrm{~m} l$ of phosphate buffered saline (Dulbecco Co., U.S. A.), while the ewes in group II were treated intramuscularly with a single dose of $15 \mathrm{mg} \mathrm{PGF} \mathrm{P}_{2 \alpha}$ (Prostin $\mathrm{F}_{2 \alpha}$ : Upjohn Co., U.S. A. ).

The treated ewes were run with a total of 5 rams of the University Farm: 1, M Farm: 2 and H Farm: 2 rams, which were fitted with harnesses and crayons. Estrous response was examined twice daily at 0800 and $1700 \mathrm{~h}$ for a period of 5 days after the treatment. Ovulation was examined by laparotomy 8 days after the treatment in randomly selected 4 ewes of each group. The ewes were examined for non-return to service by the harnessed rams 16-21 days after the treatment. Pregnancy diagnosis was carried out by an ultrasonic Doppler method between 50 and 70 days after the treatment and lambing results were also recorded.

Blood was collected from the jugular vein of 4 ewes of each group from 17 days before the sponge insertion to 20 days after the treatment. The frequency of blood collec- tion was 1-4 days intervals except for a 12 $\mathrm{h}$ interval (0600 and $1800 \mathrm{~h}$ ) during the day of estrus. Blood plasma was separated immediately after sampling and stored at $-20 \mathrm{C}$ until measurement of $E_{2}$ and $P$ by radioimmunoassay (RIA) following the method of $\mathrm{MAKINO}^{5)}$.

\section{Results}

Results are summarized in Table 1. All treated ewes in both groups I and II showed estrus within 5 days after the treatment. The distribution of the incidence of estrus was different in the two groups (Fig. 1). Namely, in group I, all ewes showed estrus within 3 days after the treatment; 9 out of 13 ewes exhibiting estrus on the second day after the treatment. On the other hand, in group II, the incidence of estrus was spread during 5 days after the treatment. Ovulation was observed in all 4 laparotomized ewes in each group and the number of ovulations per ewe (means \pm sD) were 3.25 \pm 0.63 and $1.75 \pm 0.25$ for groups $\mathrm{I}$ and II, respectively, and the difference was not significant $(t=2.22: 0.05<P<0.10)$. Non-return rates of group I $(69.2 \%)$ and group II $(66.7 \%)$ were the similar. Pregnancy and lambing rates were again not significantly different

Table 1. Responses of estrus and ovulation, and the subsequent fertility in ewes treated with MAP sponge and either PMSG or $\mathrm{PGF}_{2 \alpha}$ during the breeding season

\begin{tabular}{|c|c|c|c|c|c|c|c|}
\hline $\begin{array}{c}\text { Treatment } \\
\text { (groups) }\end{array}$ & $\begin{array}{l}\text { No. of } \\
\text { ewes }\end{array}$ & $\begin{array}{l}\text { No. of } \\
\text { ewes in } \\
\text { estrus }{ }^{1)}\end{array}$ & $\begin{array}{l}\text { No. of ewes } \\
\text { ovulated/ } \\
\text { laparotomized } \\
\text { (ovulation } \\
\text { rates) }\end{array}$ & $\begin{array}{c}\text { N.R. } \\
(16-21 \\
\text { days: } \%)\end{array}$ & $\begin{array}{c}\text { Pregnant }{ }^{2)} \\
(50-70 \\
\text { days: \%) }\end{array}$ & $\begin{array}{c}\text { Lambing } \\
(\%)\end{array}$ & $\begin{array}{c}\text { No. lambs } \\
\text { born/lambing } \\
\text { ewe }\end{array}$ \\
\hline $\begin{array}{l}\mathrm{MAP}+\mathrm{PMSG} \\
(\text { group I) }\end{array}$ & 13 & 13 & $\begin{array}{c}4 / 4 \\
(3.25 \pm 0.63)\end{array}$ & $\begin{array}{c}9 \\
(69.2)\end{array}$ & $\begin{array}{c}9 \\
(69.2)\end{array}$ & $\begin{array}{c}9 \\
(69.2)\end{array}$ & $1.67^{3)}$ \\
\hline $\begin{array}{c}\mathrm{MAP}+\mathrm{PGF}_{2 \alpha} \\
\quad \text { group II) }\end{array}$ & 15 & 15 & $\begin{array}{c}4 / 4 \\
(1.75 \pm 0.25)\end{array}$ & 10 & $\begin{array}{c}7 \\
(46.7) \\
\end{array}$ & $\begin{array}{c}7 \\
(46.7) \\
\end{array}$ & 1.43 \\
\hline
\end{tabular}

1) The period within 5 days after treatment.

2) Examined by an ultrasonic Doppler method.

3) Included 3 dead lambs. 
between the two groups $(69.2 \%$ and $46.7 \%$ for groups I and II, respectively: $\chi^{2}=1.45$ ). Nine and 7 ewes of groups I and II, respectively lambed with a pregnancy period of ranging 144 to 152 days. The number of lambs born per ewe was higher in group I than that in group II though not significantly different (1.67 and 1.43: $t=0.42$ ).

The pattern of hormonal change before and after the treatment in groups I and II

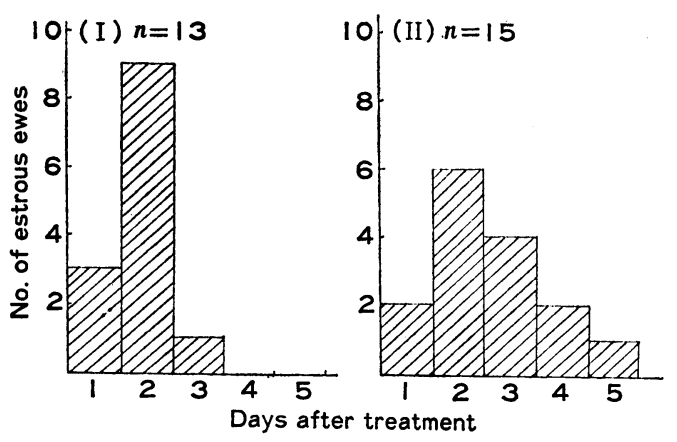

Fig. 1. Distributions of the incidence of estrus in ewes after treatment with either MAP sponge $+\mathrm{PMSG}$ (I) or MAP sponge $+\mathrm{PGF}_{2 \alpha}$ (II). are shown in Fig. 2. Changing patterns of $\mathrm{E}_{2}$ and $\mathrm{P}$ in the plasma were similar. However, the peak of the plasma $E_{2}$ level ap-

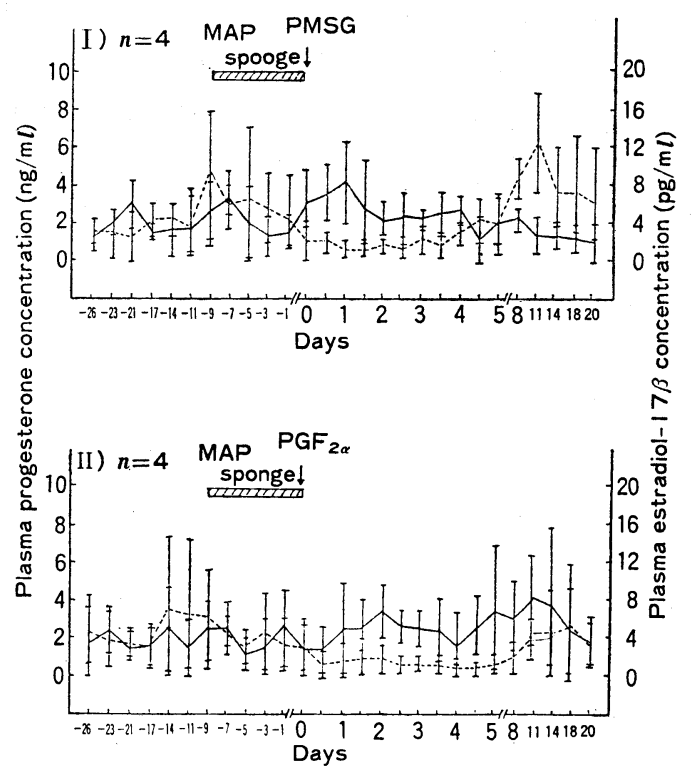

Fig. 2. Mean concentrations ( $\pm \mathrm{SD})$ of plasma estradiol-17 $\beta$ (-) and progesterone (---) in ewes treated with MAP + PMSG (I) or MAP + $\mathrm{PGF}_{2 \alpha}$ (II).
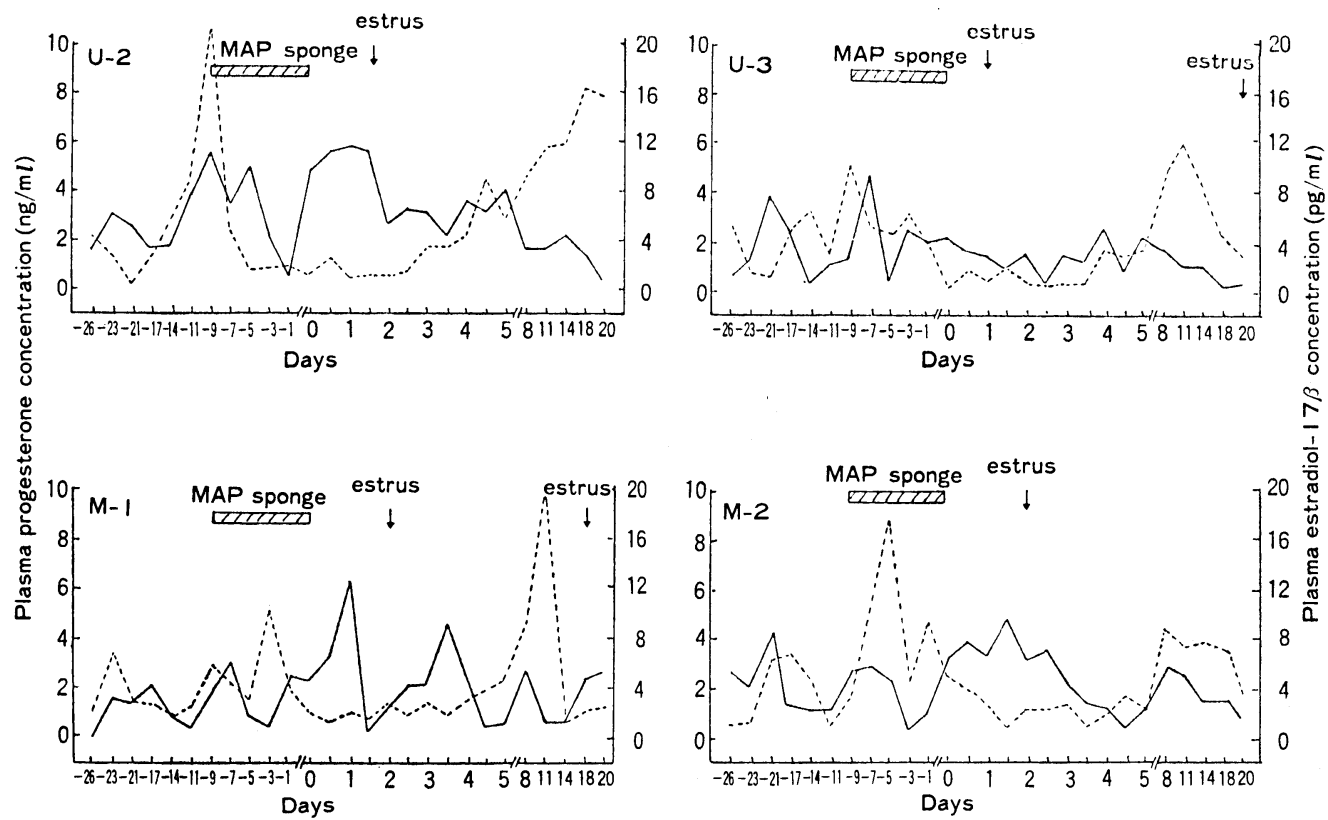

Fig. 3. Concentration of plasma estradiol-17 $\beta$ (-) and progesterone (---) in representative four ewes treated with MAP+PMSG (group I). 

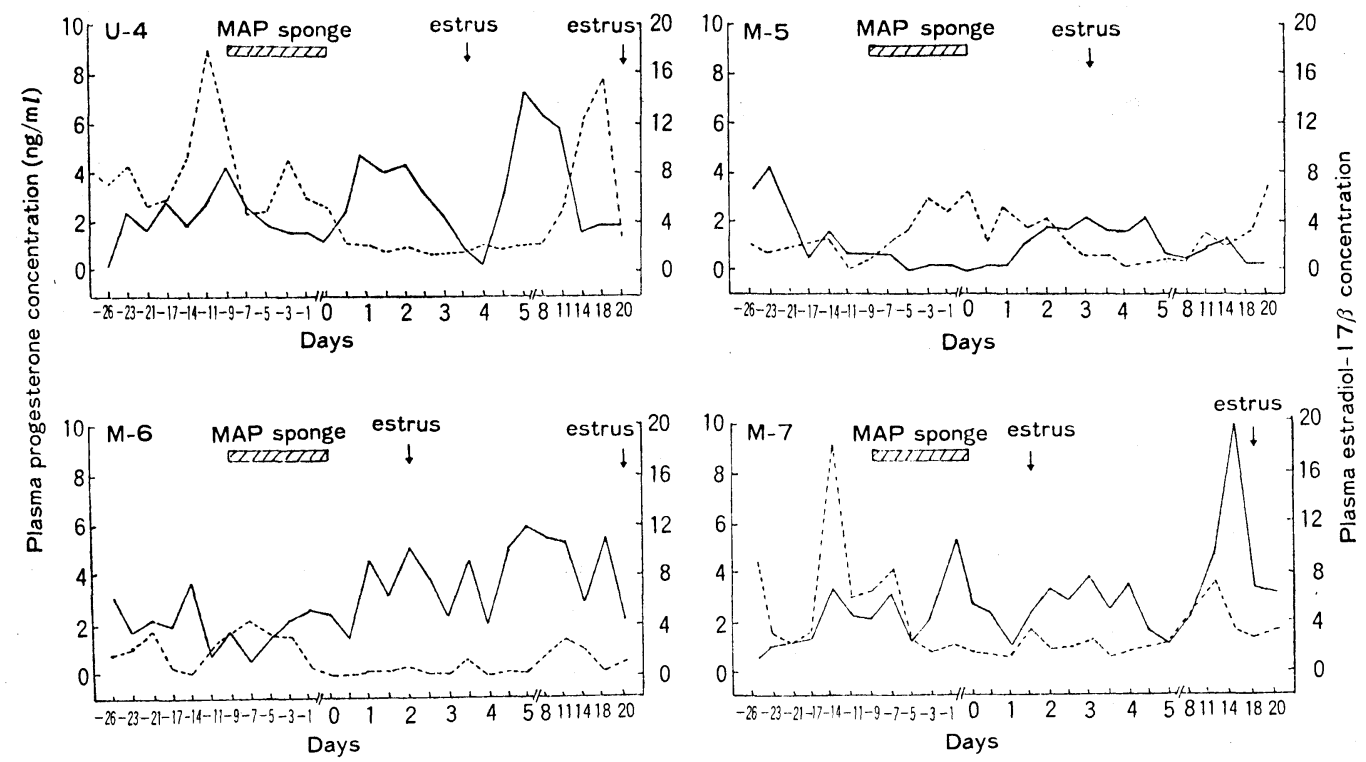

Fig. 4. Concentration of plasma estradiol-17 $\beta$ (-) and progesterone (---) in representative four ewes treated with $\mathrm{MAP}+\mathrm{PGF}_{2 \alpha}$ (group II).

peared to be one day earlier in group I than that in group II after the treatment. Figures 3 and 4 shows the hormonal change in representative four ewes of groups I and II. The $E_{2}$ level in the plasma of 4 ewes of group I became higher about half or one day before the incidence of estrus with a peak value of $9.6-12.5 \mathrm{pg} / \mathrm{ml}$ excepting the animal U-3 (Fig. 3). Similar rises of the $\mathrm{E}_{2}$ level (4.3-10.7 $\mathrm{pg} / \mathrm{m} l$ ) were observed in 4 ewes of group II (Fig. 4). Two ewes (U-2 and $M-2)$ in group $I$ and one ewe (M-5) in group II did not return to service after the first synchronized estrus. The plasma P levels in those animals were maintained at a high level $(\geq 2 \mathrm{ng} / \mathrm{ml})$ which indicated the ewes had been conceived. However, by the examination at day 50-70, only animals of M-2 (group I) and M-5 (group II) were pregnant.

\section{Discussion}

Although the administration of PMSG fol- lowing progestin treatment has been used by many workers ${ }^{6-9)}$, the combined use of $\mathrm{PGF}_{2 \alpha}$ with a short-term progestin treatment has been limited. The present study showed that a 9-day treatment of MAP sponge followed by $\mathrm{PGF}_{2 \alpha}$ injection could be successfully used for synchronization of estrus and ovulation in cycling ewes. This agrees with the results of FuKui and Roberts ${ }^{3)}$ and LoubsER and VAN NIEKERK ${ }^{4)}$ who carried out a similar treatment with $\mathrm{PGF}_{2 \alpha}$ following 7 or 8 days insertion of MAP sponges. However, in the present study, the incidence of estrous ewes after the treatment was widely spread when $\mathrm{PGF}_{2 \alpha}$ was used as compared with that of PMSG (Fig. 1). On the contrary, LOUBSER and VAN NIEKERK ${ }^{4)}$ reported a better result that $93 \%$ of ewes treated with $10 \mathrm{mg}$ of $\mathrm{PGF}_{2 \alpha}$ following MAP treatment showed estrus during 25-72 $\mathrm{h}$ after the treatment.

Although there was no significant difference on the conception rate between the two groups in the present study, the rates 
of pregnancy and lambing appeared to be higher in ewes treated with PMGS than by $\mathrm{PGF}_{2 \alpha}$ following the removal of MAP sponges. This may be due to the greater chance of conception in ewes treated with PMSG as a larger number of ovulations was observed in group I. The conception rate (average 57\%) was low, notwithstanding the use of natural mating. One of reasons to be considered for the lowered rate of conception could be early embryonic deaths during the period of day 21-50 caused by unknown factors in group II. However, in group I, the lambing rate was similar with the result of HACKETT et al. ${ }^{10)}(69 \%$ vs $66 \%)$. It has been reported that the response to a given dose of PMSG may remarkedly be affected by factors such as seasons of the year, age of animals, nutrition, and strain and breed of the ewe $\mathrm{e}^{9.11-13)}$.

Fukur et al. ${ }^{14)}$ conducted a similar experiment to the present study in ewes during the non-breeding season and found that $\mathrm{PGF}_{2 \alpha}$ injection following MAP sponge treatment was unsuccessful for the induction of estrus and ovulation. However, a high peak of $\mathrm{E}_{2}(10.0-12.9 \mathrm{pg} / \mathrm{ml})$ in the plasma was within 5 days after the treatment which was similar in concentration and pattern to those of the estrous ewes following MAP and PM. SG treatment $(7.7-12.9 \mathrm{pg} / \mathrm{ml})$. In the present study, the plasma $E_{2}$ levels in ewes treated with $\mathrm{PGF}_{2 \alpha}$ following the sponge removal were between 4.7 and $10.7 \mathrm{pg} / \mathrm{ml}$. All treated ewes were in estrus and all of the 4 laparotomized ewes ovulated. Regardless of season, plasma $\mathrm{E}_{2}$ concentration greater than $4 \mathrm{pg} / \mathrm{m} l^{15)}$ or with the range of 3 $7 \mathrm{pg} / \mathrm{m} l^{16)}$ can induce estrous behavior and produce a surge of luteinizing hormone $(\mathrm{LH})$ in ewes. Plasma $E_{2}$ may be less effective in inducing $\mathrm{LH}$ release and subsequent ovulation in anestrous ewes during the non-breeding season ${ }^{17}$, but this may not be so in cycling ewes during the breeding season.

The present study indicates that PMSG treatment following 9 days of MAP vaginal sponge appeared to be more effective than MAP and PGF $_{2 \alpha}$ treatment for synchroniza. tion of estrus and ovulation, and the subsequent fertility.

Acknowledgments We thank Messers. K. TAKAHASHI and Y. ОнмоRI for their interests, and Prof. M. Miyake for hormonal assay and reading the manuscript. We also wish to thank Teikokuzōki Co., Japan for the supply of PMSG, and Upjohn Co., Australia and Japan for the gifts of MAP sponges and $\mathrm{PGF}_{2 \alpha}$, respectively.

\section{References}

1) Robinson, T. J.: Proc. Int. Congr. Anim. Reprod. \& A. I., Paris, 2, 1347, 1968.

2) Hackett, A. J., H. A. Robertson \& H.F. PetERS: J. Anim. Sci., 45, Supplement 1, 165, 1977.

3) Fukui, Y. \& E. M. Roberts: Jpn. J. Anim. Reprod., 25, 131, 1979.

4) Loubser, P. G. \& C. H. van Niekerk: Theriogenology, 15, 547, 1981.

5) Makino, T.: Folia Endocr. Japon,: 49, 629, 1973.

6) Dzıuк, P. J.: Proc. Confer. on Estrus Cycle in Domestic Animals, Lincoln, Nebraska, pp. 50, U.S. Dept. Agric. \& Univ. Nebraska, 1964.

7) Roche, J. F.: Irish J. Agric. Res., 7, 1, 1968.

8) Gordon, I.: Wld. Rev. Anim. Prod., 9, 19, 1973.

9) Laster, D. B. \& H. A. Glimp: J. Anim. Sci., 39, 1129, 1974.

10) Hackett, A. J., H. A. Robertson \& M.S. Wolymetz: J. Anim. Sci., 53, 154, 1981.

11) Robinson, T. J.: J. Agric. Sci., Cambridge, 41, 6, 1951.

12) Wallace, L. R.: J. Agric. Sci., Cambridge, 45, 60, 1954.

13) Braden, A. W. H., D. R. Lamond \& H. M. Rad. FORD: Aust. J. Agric. Res., 11, 389, 1960.

14) Fukui, Y., W. L. Sotto, Y. Terawaki \& H. Ono: Res. Bull. Obihiro Univ., Ser. II, 12, 339, 1982.

15) Goodman, R. L. \& F. J. Karsch: Progress in Reprod. Biol. 5, Seasonal Reproduction in 
Higher Vertebrates. (Reiter R. J. \& B. K. FolLETT eds.) pp. 134, S. Karger, Basel, 1980.

16) Karsch, F. J., D. L. Foster, S. J. Legan, K. D. Ryan \& G. K. Peter: Endocrinology, 105, 421,
1979.

17) Land, R. B., A. G. Wheeler \& W. R. Carr: Ann. Biol. Anim. Biochim. Biophis., 16, 521, 1976. (Received August 19, 1982)

\section{黄体ホルモン処置後の PMSG または $\mathrm{PGF}_{2 \alpha}$ による めん羊の発情・排卵同期化について}

\section{福井 豊・W. L. Sотто ・ 小野 斉}

(帯広畜産大学肉畜增殖学教室)

めん羊の繁殖季節 $(9 \sim 11$ 月）において，コリデール 種, サフォーク種とその両種の雑種, 計 28 頭の成熟雌羊 を用いて発情および排卵の同期化を試みた。方法は, 全 頭に合成黄体ホルモン (Methyl-acetoxyprogesterone: MAP) $60 \mathrm{mg}$ を含む胵内スポソジを 9 日間腔深部に插 入した。腔内スポンジ除去直後, 雌羊を 2 群に別け, 750 IU の PMSG（I 群：13 頭）または $15 \mathrm{mg}$ の $\mathrm{PGF}_{2 \alpha}$ （II 群：15 頭）を各々筋肉内注射した。その後，マーキ ング・ハーネスを付着した正常雄羊を雌羊群に 5 日間同 居させた。朝・タ（ 8 時と 5 時）にクレヨンでマークさ れた雌羊を発情と判定した。排卵は処置後 8 日目に各群 の 4 頭を開腹し, 新生黄体の存在により確認した。受胎 率として, Non-Return (N.R. 16 21 日), 超音波ドッ プラー法による妊娠診断 $(50 \sim 70$ 日) および分婏率を記 録した。また，黄体ホルモン処置前 17 日から処置後 20 日までの期間, 0.5 3 日間隔で各群 4 頭において頸静 脈から採血し，血漿中のプロジェステロン (P) とェス
トラジオール-17 $\beta\left(\mathrm{E}_{2}\right)$ 濃度をRIA 法により測定した。 両群の全頭が処圆後 5 日以内に発情を示した。発情の 同期化については，I群が良好であった。すなわち，I 群の 13 頭はすべて処置後 3 日以内に発情を示した。排 卵は，I， II 群の各々 4 頭すべてに観察された(排卵数： $3.25 \pm 0.63,1.75 \pm 0.25)$ 。両群に扔いて, N.R. 率, 妊 娠率, 分婏率扣上び婏出子羊数/分婏母羊数は以下の とおりである：I群； 69\%，69\%，69\% そして 13/9 (1.67)，II群； $67 \% ， 47 \% ， 47 \%$ そして 9/7 (1.43)。 両群に拈ける受胎率および娩出子羊率に有意な差は衿め られなかった。血漿中の $\mathrm{P}$ 版び $\mathrm{E}_{2}$ レベルの変化は両 群において類似していた。

以上の成績から, 繁殖季節に拈けるめん羊の発情およ び排卵の同期化は MAP スポンジ $+\mathrm{PGF}_{2 \alpha}$ 処置よりも MAP スポンジ+PMSG 処置の方が良好であるように思 われた。 